\title{
Aphicidal activity of Bacillus amyloliquefaciens strains in the peach-potato aphid (Myzus persicae)
}

\author{
Guadalupe López-Isasmendi $^{\mathrm{a}, \mathrm{b}}$, Adriana Elisabet Alvarez ${ }^{\mathrm{a}}$, Gabriela Petroselli ${ }^{\mathrm{c}}$, \\ Rosa Erra-Balsells ${ }^{\mathrm{c}}$, Marcela Carina Audisio ${ }^{\mathrm{d}, *}$ \\ ${ }^{\text {a }}$ Facultad de Ciencias Naturales, Universidad Nacional de Salta, Salta, Argentina \\ ${ }^{\mathrm{b}}$ CONICET, CCT-Salta, Salta, Argentina \\ ${ }^{\mathrm{c}}$ CIHIDECAR-CONICET, Departamento de Química Orgánica, Facultad de Ciencias Exactas y Naturales, Universidad de Buenos Aires, Pabellón II, 3 Ciudad Universitaria, \\ 1428, Buenos Aires, Argentina \\ ${ }^{\mathrm{d}}$ Instituto de Investigaciones para la Industria Química (INIQUI-CONICET), Universidad Nacional de Salta, Av. Bolivia 5150, 4400 Salta, Argentina
}

\section{A R T I C L E I N F O}

\section{Keywords:}

Hemiptera: Aphididae

Bacterial metabolites

Insecticide

Microbial pesticide

Biocontrol

\begin{abstract}
A B S T R A C T
Myzus persicae Sulzer (Hemiptera: Aphididae), is a generalist cosmopolitan insect that infests more than 400 plant species of 40 different families and is one of the major pests infesting potato crops. It causes direct damage and also spread plant viruses. The intensive use of synthetic insecticide to control aphids has led to resistant populations. Therefore, there is a need to develop biopesticides for effective control that minimizes environmental hazards. The bacteria Bacillus amyloliquefaciens is recognized as a producer of a variety of bioactive compounds. The aim here was to evaluate the aphicidal effect of $B$. amyloliquefaciens strains, CBMDDrag3, PGPBacCA2, and CBMDLO3, and their metabolites on the mortality and fecundity of M. persicae. Cells suspensions, heat-killed cell suspensions, cell-free supernatants, or isolated lipopeptide fractions from B. amyloliquefaciens strains were offered to aphids through artificial diets. The isolated lipopeptide fractions composed mainly of kurstakins, surfactins, iturins, and fengycins, when were administrated through diets, had no aphicidal effect against $M$. persicae. However, aphids fed on diets with whole cell suspensions and its cell-free supernatant of all three bacteria strains resulted in $100 \%$ mortality of adult aphids and nymphs. Specially, B. amyloliquefaciens CBMDLO3, has an effective aphicidal effect on $M$. persicae, used both bacterial cells and their metabolites. Moreover, heat-killed cells of $B$. amyloliquefaciens CBMDLO3 also had aphicidal action, although the aphid mortality was lower than on diet with living bacteria. Therefore, these results propose that B. amyloliquefaciens, could function as a novel eco-friendly biopesticide for the control of $M$. persicae.
\end{abstract}

\section{Introduction}

The peach-potato aphid, Myzus persicae Sulzer (Hemiptera: Aphididae), is a generalist cosmopolitan insect that infests more than 400 plant species of 40 different families such as Solanaceae, Asteraceae, Malvaceae, Brasicaceae, Amaranthaceae, Rosaceae, Curcubitaceae, among others (Blackman, 1974a,b) and is one of the mayor pests infesting potato crops (Hill, 2008; Kuroli and Lantos, 2006). In potato crops, $M$. persicae causes damage by removing nutrients from the plant, by secreting honeydew which causes a secondary growth of fungi that inhibits photosynthesis, and by inoculating plant viruses (Castle and Berger, 1993; Salazar, 1996).

Myzus persicae is a piercing-sucking insect that ingests plant phloem fluid through the stylets, modified mouthparts that are used to penetrate the plant tissues (Tjallingii and Hogen Esch, 1993). Their feeding behavior, made aphids the most efficient vector of plant viruses (Loebenstein et al., 2001; Radcliffe and Ragsdale, 2002). Particularly, in vegetatively propagated crops, such as potato crops, virus dispersion is significantly higher in the presence of aphids, which reduces the performance of crops by up to 90\% (Jeffries, 1998).

Potato growers, in order to keep potato crops virus-free, apply an intensive aphid control scheme that requires multiple insecticide applications, which frequently results in the development of resistant populations; in particular $M$. persicae display several types of resistance to insecticides (Devonshire and Field, 1991; Devonshire et al., 1998; Moores et al., 1994; Simon and Peccoud, 2018; van Toor et al., 2008). Seed potato crops are commonly treated with neonicotinoids, specially imidacloprid (van Toor et al., 2008), although $M$. persicae was

\footnotetext{
* Corresponding author.

E-mail address: audisio@unsa.edu.ar (M.C. Audisio).
} 


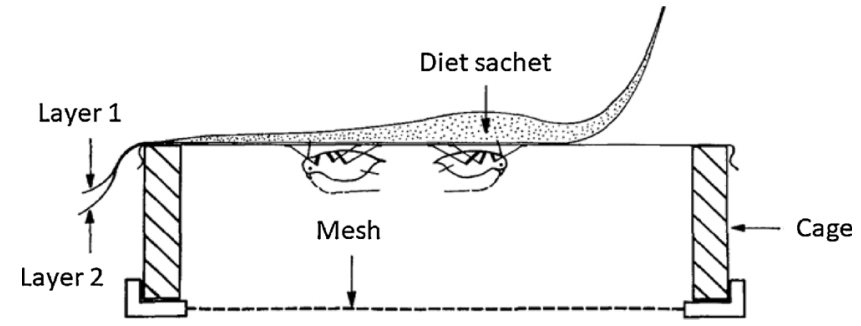

Fig. 1. Artificial diet cages: a plastic cylinder of $3 \mathrm{~cm}$ height $\times 3792 \mathrm{~cm}$ wide, with a mesh on the bottom and the top opened. On this opened side the diet sachet was 380 applied (diet solution between two layers of Parafilm) (Machado-Assefh and Alvarez, 2018).

occasionally registered as resistant to neonicotinoids (Bass et al., 2011; Garzo et al., 2015; van Toor et al., 2013). Also use of synthetic insecticides produce environmental impacts, including poisoning of humans; destruction of wildlife; disruption of natural biological control and pollination (Atanasova and Leather, 2018); soil and groundwater contamination, and the evolution of resistance to pesticides in other pest populations (Ekström and Ekbom, 2011; Isman, 2006). Hence, there is an urgent need to develop biopesticides for effective control of agricultural pests without causing serious harm to the environment (Carlini and Grossi-de-Sá, 2002; Mnif and Ghribi, 2015).

A biopesticide is a mass-produced agent manufactured from a living microorganism or a natural product, and sold for the control of plant pests (Mnif and Ghribi, 2015). In recent years, the use of biopesticides has increased, and it is estimated that $50 \%$ of the biopesticides active substances registered in EU and USA come from microorganisms, and are referred to as microbial pesticides (Chandler et al., 2011). Among the beneficial bacteria used as biocontrol agents are several species of Bacillus, Gram-positive and spore-forming bacteria capable of colonizing the roots and the rhizosphere with beneficial effects on plants, and therefore are designated as plant growth-promoting rhizobacteria (PGPR) (Zouari et al., 2016). In addition, the genus Bacillus has been studied due to its capacity to produce a diversity of secondary metabolites with interesting biological activities, especially non-ribosomal synthesized cyclic lipopeptides (LPs) such as, surfactin, iturin and fengycin (Mnif and Ghribi, 2015; Ongena and Jacques, 2007). These compounds have a hydrophilic peptide part and a hydrophobic alkyl chain, and may differ on the amino acid sequence and fatty acid branching. They are characterized by a low toxicity, high biodegradability, and for being environmentally friendly; but they exhibit significant inhibitory activity on viruses, bacteria, fungi, oomycetes and mosquitoes (Kim et al., 2004; Ongena et al., 2005; Porrini et al., 2010; Sabaté et al., 2009). Bacillus amyloliquefaciens is a bacteria recognized for producing microbial pesticide, with an array of bioactive compounds with fungicide effect (Alvarez et al., 2012; Torres et al., 2017;
Zouari et al., 2016), aphicidal effect against M. persicae (Yun et al., 2013), and biosurfactants with mosquitocidal effect against the mosquitoes Aedes stephensi, Culex quinquefasciatus and Aedes aegypti (Geetha et al., 2011) and insecticidal activity against larvae of Spodoptera littoralis and Tuta absoluta (Ben Khedher et al., 2017, 2015). In addition, B. amyloliquefaciens has a protective antiviral effect on tomato against TSWV and PVY viruses (Beris et al., 2018). The objective of this work was to assess the effect of $B$. amyloliquefaciens strains and their metabolites on the mortality and fecundity of $M$. persicae.

The aphicidal effect of $B$. amyloliquefaciens was evaluated in bacterial cells suspensions, heat-killed cell suspensions, cell-free supernatants, and isolated lipopeptide fractions. This work aims to contribute in the search for new environmentally friendly products of bacteria origin to control aphids.

\section{Materials and methods}

\subsection{Aphids}

Myzus persicae Sulzer was reared on radish (Raphanus sativus L). Aphids used in the experiments came from a colony maintained at the Faculty of Natural Science (National University of Salta, Salta, Argentina). This colony was initiated from a single virginoparous apterous individual collected in field in 2009. The colony was reared in a climate chamber at $22 \pm 2{ }^{\circ} \mathrm{C}, 30-40 \%$ R.H., and $16 / 8 \mathrm{~h}$ light/ dark photoperiod to induce parthenogenesis. A new colony was started every week, and newly moulted apterae adult aphids were used for the experiments.

Microorganisms, suspensions of bacterial cells (CS), heat-killed cell suspension (hkCS), cell-free supernatants (CFS), and isolated lipopeptide fractions (LF)

Bacillus amyloliquefaciens strain CBMDDrag3 (GenBank access code JX120510) B. amyloliquefaciens PGPBacCA2 (GenBank access code JX120521), and B. amyloliquefaciens CBMDLO3 (GenBank access code JX12506) isolated from a honey sample and from an air sample, were cultivated at the Laboratory of Applied Bacteriology of INIQUICONICET. These strains were grown in Luria Bertani (LB) (Britania, Argentina) at $37^{\circ} \mathrm{C}$.

To obtain the CS, LB broth was inoculated with a pure culture of each bacterial strain in a percentage of $2 \%(\mathrm{v} / \mathrm{v})$ and incubated for 1,4 and 6 days, at $37^{\circ} \mathrm{C}$, without agitation. Concentrations of about $1 \times 10^{8}$ cells/ $\mathrm{mL}$ were obtained. Then, $50 \mu \mathrm{L}$ of each culture were suspended on $5 \mathrm{~mL}$ of peptone water. The number of cells was determined by counting serial dilutions in peptone water on LB agar plates.

The CFS fractions were obtained from CS by centrifugation at $10,000 \mathrm{~g}, 10 \mathrm{~min}$ at $4{ }^{\circ} \mathrm{C}$, and filtrated with a sterilized cellulose acetate filter of $0.22 \mu \mathrm{m}$ pore-size and kept at $4^{\circ} \mathrm{C}$ until further analysis.

The LF fractions were obtained from CFS of strains CBMDDrag3 and CBMDLO3. CFS were centrifuged and acidified to $\mathrm{pH} 2$ with

Table 1

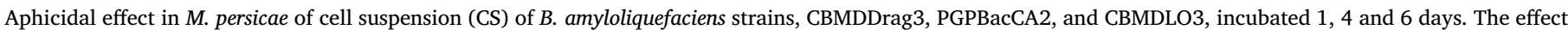
was observed after 4 days of feeding on artificial diets containing $10 \mu \mathrm{L}$ of CS per $100 \mu \mathrm{L}$ of diet, Numbers are means ( \pm SE) of aphids, adults and nymphs.

\begin{tabular}{|c|c|c|c|c|c|c|c|c|c|c|c|c|c|}
\hline \multirow[t]{2}{*}{ Treatment } & \multirow[t]{2}{*}{ Diet control $n=8$} & \multirow[t]{2}{*}{ Diet + peptone water $n=9$} & \multicolumn{3}{|c|}{ CBMDDrag3 $\mathrm{n}=10$} & \multicolumn{3}{|c|}{ PGPBacCA2 $\mathrm{n}=10$} & \multicolumn{3}{|c|}{ CBMDLO3 $\mathrm{n}=10$} & \multirow[t]{2}{*}{$\mathrm{H}$} & \multirow[t]{2}{*}{$\mathrm{P}$} \\
\hline & & & 1 day & 4 days & 6 days & 1 day & 4 days & 6 days & 1 day & 4 days & 6 days & & \\
\hline Adults alive & $4.25 \pm 0.37 \mathrm{a}$ & $4.6 \pm 0.16 \mathrm{a}$ & $0 \mathrm{~b}$ & $0 \mathrm{~b}$ & $0 \mathrm{~b}$ & $0 \mathrm{~b}$ & $0 \mathrm{~b}$ & $0 \mathrm{~b}$ & $0 \mathrm{~b}$ & $0 \mathrm{~b}$ & $0 \mathrm{~b}$ & 44.6 & $<0.0001$ \\
\hline Nymphs alive & $37.88 \pm 5.87 \mathrm{a}$ & $47.7 \pm 1.99 \mathrm{a}$ & $0 \mathrm{~b}$ & $0 \mathrm{~b}$ & $0 \mathrm{~b}$ & $0 \mathrm{~b}$ & $0 \mathrm{~b}$ & $0 \mathrm{~b}$ & $0 \mathrm{~b}$ & $0 \mathrm{~b}$ & $0 \mathrm{~b}$ & 44.65 & $<0.0001$ \\
\hline
\end{tabular}

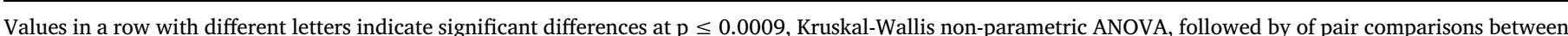
means of treatments with Bonferroni correction. 
concentrated $\mathrm{HCl}$, the precipitated lipopeptides were recovered by centrifugation at $14,000 \mathrm{~g}, 25 \mathrm{~min}$ at $4{ }^{\circ} \mathrm{C}$, and extracted with $10 \mathrm{~mL}$ of methanol. Then, the solvent was evaporated and the precipitate were dissolved in sterile distilled water and adjusted to $\mathrm{pH} 8-9$ with $0.5 \mathrm{M}$ $\mathrm{NaOH}$. The LF final concentration were, $5.8 \mathrm{mg} / \mathrm{mL}$ for CBMDDrag3, and $5 \mathrm{mg} / \mathrm{mL}$ for CBMDLO3.

A heat-killed cell suspension (hkCS) of the strain CBMDLO3, was obtained from a 4-day culture by autoclaving at $121^{\circ} \mathrm{C}, 15 \mathrm{~min}$.

CFS of CBMDDrag3 and CBMDLO3 were analysed by UV-MALDI TOF. The main lipopeptides were identified, and spectra were recorded on a Bruker Ultraflex II TOF/TOF (Bruker Daltonics, Bremen, Germany) using 9 Hpyrido [3,4b]-indole (norharmane, $\mathrm{nHo}$ ) as a matrix in positive ion mode. Two spots (technical replicates) were analyzed from each sample.

\subsection{Aphicidal assays with B. amyloliquefaciens strains}

The biological effect of $B$. amyloliquefaciens strains on $M$. persicae were assessed by offering the insects with artificial diets supplemented with CS, CFS, hkCS or FL, and after 4 days the adults mortality and the number of nymphs, alive and dead, were counted. The aphid's artificial diets contained $150 \mathrm{mM}$ amino acids, $500 \mathrm{mM}$ sucrose, vitamins, and minerals and were administrated through parafilm sachets on diet cages as previously described (Fig. 1) (Machado-Assefh et al., 2015; Prosser and Douglas, 1991). Diet cages consisted on plastic cylinders $(3 \mathrm{~cm}$ diameter and $2 \mathrm{~cm}$ high) sealed on top with a diet sachet containing $100 \mu \mathrm{L}$ of diet solution between two layers of Parafilm, and sealed at the bottom with a mesh (Koga et al., 2007; Prosser and Douglas, 1991). Five recently moulted apterae adult aphids were placed on the diet cages and were maintained in a climate chamber at $22 \pm 2{ }^{\circ} \mathrm{C}, 30-40 \%$ R.H., in darkness. After 4 days of treatment, the number of adults and offspring, dead or alive, were counted per cage.

Five assays were carried using $100 \mu \mathrm{L}$ of artificial diet, each with an added portion of the different $B$. amyloliquefaciens strain derivatives, as follows: 1) $10 \mu \mathrm{L}$ of $\mathrm{CS}$ from strains CBMDDrag3, PGPBacCA2, or CBMDLO3, on days 1, 4, and 6 after incubation; controls were plain diet and diet with $10 \mu \mathrm{L}$ of peptone water; 2) $10 \mu \mathrm{L}$ of CFS from strains CBMDDrag3, PGPBacCA2, or CBMDLO3, on days 1, 4, and 6 days after incubation; controls were plain diet and diet with $10 \mu \mathrm{L}$ of LB medium; 3) 1, 5 and $10 \mu \mathrm{L}$ CFS from strains CBMDDrag3 and CBMDLO3 on day 4 day after incubation; control was only plain diet; 4) $10 \mu \mathrm{L}$ of CS and hkCS from strain CBMDLO3 on day 4 after incubation; controls were plain diet and diet with $10 \mu \mathrm{L}$ of LB medium; 5) LF from CBMDDrag3 at a concentration of $5.8,14.5,29$ and $58 \mu \mathrm{g}$ of $\mathrm{LF}$ on $100 \mu \mathrm{L}$ of diet, and LF from CBMDLO3 at 5, 12.5, 25 and $50 \mu \mathrm{g} / 100 \mu \mathrm{L}$ of diet; controls were plain diet and diet plus $10 \mu \mathrm{L}$ of distilled water at $\mathrm{pH} 8$.

Assay 1) was repeated twice, and assays 2), 3), 4) and 5), were run in triplicate; in all cases, they were carried out under the same conditions and using the same solutions of CS, CFS, hkCS, and LF. The final number of replicates per assay 1 ) was $n=10$, whereas for assays 2), 3), 4 ) and 5) the number of replicates varied between $n=10-15$.

\subsection{Statistics analysis}

The aphicidal effect of B. amyloliquefaciens strains on M. persicae, based on mortality of adults, number of nymphs, and total number of nymphs alive and dead, was analyzed by the Kruskal-Wallis nonparametric analysis of variance at one way of classification, followed by multiple comparisons between means of treatments with Bonferroni correction (Weisstein, 1999). Analysis were conducted with InfoStat 2015 (Di Rienzo et al., 2015).

\section{Results}

The potential aphicidal effect of the CS, CFS and LF of B. amyloliquefaciens CBMDDrag3, PGPBacCA2 and CBMDLO3 strains, was 
Table 3

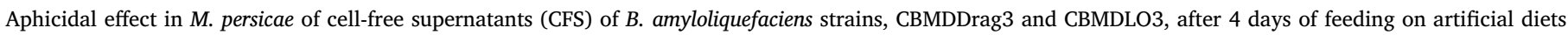
containing 1,5 and $10 \mu \mathrm{L}$ of CFS per $100 \mu \mathrm{L}$ of diet. Numbers are means ( \pm SE) of aphids, adults and nymphs.

\begin{tabular}{|c|c|c|c|c|c|c|c|c|c|}
\hline \multirow[t]{2}{*}{ Treatment } & \multirow{2}{*}{$\begin{array}{l}\text { Diet control } \\
\mathrm{n}=12\end{array}$} & \multicolumn{3}{|l|}{ CBMDDrag3 } & \multicolumn{3}{|l|}{ CBMDLO3 } & \multirow[t]{2}{*}{$\mathrm{H}$} & \multirow[t]{2}{*}{$\mathrm{P}$} \\
\hline & & $1 \mu \mathrm{L} \mathrm{n}=15$ & $5 \mu \mathrm{L} \mathrm{n}=14$ & $10 \mu \mathrm{L} \mathrm{n}=15$ & $1 \mu \mathrm{L} \mathrm{n}=15$ & $5 \mu \mathrm{L} \mathrm{n}=15$ & $10 \mu \mathrm{L} \mathrm{n}=15$ & & \\
\hline Adults alive & $4.67 \pm 0.19 c$ & $3.29 \pm 0.46 \mathrm{bc}$ & $1.93 \pm 0.44 \mathrm{~b}$ & $2.53 \pm 0.49 \mathrm{~b}$ & $0.07 \pm 0.07 \mathrm{a}$ & $0 \mathrm{a}$ & $0.07 \pm 0.07 \mathrm{a}$ & 56.2 & $<0.0001$ \\
\hline Nymphs alive & $63.08 \pm 2.02 c$ & $33.36 \pm 8.36 \mathrm{~b}$ & $16.8 \pm 4.63 b$ & $16.93 \pm 4.87 b$ & $0.07 \pm 0.07 \mathrm{a}$ & $0.87 \pm 0.64 a$ & $0 \mathrm{a}$ & 51.63 & $<0.0001$ \\
\hline Total nymphs & $63.08 \pm 2.02 c$ & $44.64 \pm 5.58 \mathrm{bc}$ & $29.93 \pm 3.62 \mathrm{~b}$ & $30.87 \pm 4.18 b$ & $16.27 \pm 2.66 \mathrm{a}$ & $13.2 \pm 1.65 \mathrm{a}$ & $8.6 \pm 1.59 \mathrm{a}$ & 63.58 & $<0.0001$ \\
\hline
\end{tabular}

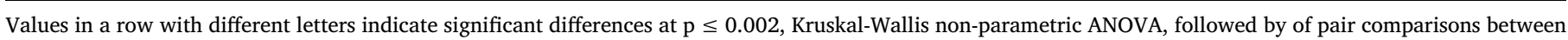
means of treatments with Bonferroni correction.

Table 4

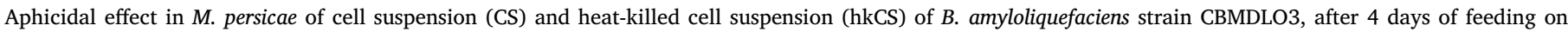
artificial diets containing $10 \mu \mathrm{L}$ of CS or hkCS per $100 \mu \mathrm{L}$ of diet. Numbers are means ( \pm SE) of aphids, adults and nymphs.

\begin{tabular}{|c|c|c|c|c|c|c|}
\hline \multirow[t]{3}{*}{ Treatment } & \multirow{3}{*}{$\begin{array}{l}\text { Diet control } \\
\mathrm{n}=14\end{array}$} & \multirow{3}{*}{$\begin{array}{l}\text { Diet }+ \text { LB } \\
\mathrm{n}=14\end{array}$} & \multicolumn{2}{|c|}{ CBMDLO3 } & \multirow[t]{3}{*}{$\mathrm{H}$} & \multirow[t]{3}{*}{$\mathrm{P}$} \\
\hline & & & \multicolumn{2}{|c|}{$\mathrm{n}=15$} & & \\
\hline & & & $\mathrm{CS}$ & hkC & & \\
\hline Adults alive & $3.07 \pm 0.43 \mathrm{a}$ & $3.21 \pm 0.42 \mathrm{a}$ & $0 \mathrm{c}$ & $1.27 \pm 0.32 \mathrm{~b}$ & 44.41 & $<0.0001$ \\
\hline Nymphs alive & $23.93 \pm 3.94 \mathrm{a}$ & $28.86 \pm 5.17 \mathrm{a}$ & $0 \mathrm{c}$ & $6.20 \pm 1.86 \mathrm{~b}$ & 49.06 & $<0.0001$ \\
\hline
\end{tabular}

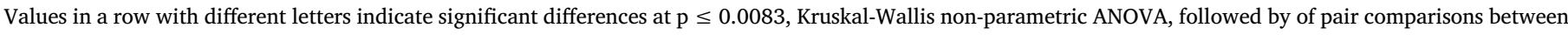
means of treatments with Bonferroni correction.

evaluated on $M$. persicae after 4 days of feeding on artificial diet.

Aphids fed on diets with CS of B. amyloliquefaciens CBMDDrag3, PGPBacCA2, and CBMDLO3 at 1, 4, and 6 days post incubation, caused $100 \%$ adult mortality and no nymphs were found, alive or dead (Table 1). Aphids fed on diets with CFS from strain PGPBacCA2 and CBMDLO3 at 1, 4, and 6 days, caused 100\% mortality of adults and nymphs. Although in diets with CFS, several nymphs were found, all were dead and the numbers were significantly lower than in the control at all incubation times (Table 2). On diets supplemented with CFS from CBMDDrag3 strain, after 1 day of incubation, the number of total nymphs, although dead, did not differ from the controls (Table 2). Aphids fed on diets in different concentrations of CFS, with an incubation period of 4 days, had a significant mortality of adults and nymphs at 5 and $10 \mu \mathrm{L} / 100 \mu \mathrm{L}$ of diet of CFS of strain CBMDDrag3, and at 1,5 and $10 \mu \mathrm{L} / 100 \mu \mathrm{L}$ of diet of CFS of strain CBMDLO3 (Table 3). Aphids fed on diets with hkCS of strain CBMDLO3, had significant more mortality of adults and nymphs than aphids in control diet and in diet LB control, although the mortality of adults and nymphs is significantly lower than on diet with CS (Table 4).

Finally, the LFs extracted from the CFS of B. amyloliquefaciens CBMDDrag3 and CBMDLO3 and, in all of the concentrations tested, had no aphicidal effect on $M$. persicae (Table 5).

The lipopeptides produced by $B$. amyloliquefaciens CBMDDrag3 and CBMDLO3 incubated for 4 days were analyzed in cell-free supernatant of each strain, respectively, using UV-MALDI TOF. The compounds found fell into two $\mathrm{m} / \mathrm{z}$ ranges $850-1200$ (Fig. 2), which includes kurstakins, surfactins and iturins and m/z 1400-1700 (Fig. 3), which includes fengycins. Lipopeptide homologues were observed as protonated, sodiated and/ or potasiated adducts (Table 6). Cyclic homologues from kurstakin were detected as potasiated adducts at $\mathrm{m} / \mathrm{z}$ 890.65, 902.88 and 917.21. Additionally, surfactin homologues were observed as adduct of sodium at $\mathrm{m} / \mathrm{z} 1015.06,1031.11,1045.28$ and 1059.34 (Fig. 2, Table 6). These peaks revealed differences of $14 \mathrm{~m} / \mathrm{z}$ unities, suggesting a series of homologous molecules having different lengths of fatty acid chains (i.e., $\mathrm{CH} 2=14 \mathrm{Da}$ ). Mass spectra profiles were similar for both strains under the study CBMDLO3 (Fig. 2a) and CBMDDrag3 (Fig. 2b). Fengycin A and fengycin B homologues were also detected in CBMDLO3 and CBMDDrag3 samples (Fig. 3). However, the intensity of the signals was higher in CBMDLO3 than in CBMDDrag3.

\section{Discussion}

Our results revealed that all strains of $B$. amyloliquefaciens have aphicidal activity against $M$. persicae. Our findings also suggest that $B$. amyloliquefaciens could function as a biocontroller in three ways: (a) as a bacterial cellular suspension (CS) containing the viable bacterial cells, spores, and their metabolites; (b) as heat-killed cell suspension (hkCS); and (c) as cell-free supernatant (CSF) containing only the bacteria metabolites. We found that mortality time (before the appearance of nymphs) varied between CS and hkCS, or CSF. All evaluated B. amyloliquefaciens elicited some lethal action on $M$. persicae, but mortality was strain- and treatment-dependent. No live or dead nymphs were found in diets with CS but some dead and alive nymphs were found in diets containing CFS or hkCS. The presence of nymphs (dead or alive) could indicate that adult aphids took longer time to die on CFS or hkCS than on diets containing the living bacteria (CS). The presence of living cells of $B$. amyloliquefaciens inside aphids may also have an inhibitory effect on their fertility. Our results suggest that viable bacterial cells and their active enzymes are key in their aphicide activity on $M$. persicae. Stavrinides et al. (2009) found that the plant pathogenic bacteria Pseudomonas syringae could be ingested by the aphid Acyrthosiphon pisum and migrate through the digestive tract, establish in the gut, and multiply. High titers of these bacteria are lethal for aphids, which stop feeding and begin to wander, continually depositing infected honeydew over plant surfaces.

Among the possible cause of mortality in aphids, an effect on the aphid endosymbionts Buchnera aphidicola should also be considered. $B$. 
aphidicola is a Proteobacteria and an obligatory endosymbiont, which produces essential amino acids that supplement aphid diet (Douglas, 1996). When B. aphidicola are eliminated by chemical or antibiotic treatments, the aposymbiotic aphids are sterile, show reduced performance and increased mortality (Douglas, 1998), and a constrained feeding behavior (Machado-Assefh and Alvarez, 2018). Here, we hypothesized that once $B$. amyloliquefaciens cells are ingested by $M$. persicae, the insect succumbs, either due to a competition with the endosymbiont $B$. aphidicola or due to a bacterial sepsis. The final mechanism/s involved must be further evaluated.

Regarding the incubation time of $B$. amyloliquefaciens that is needed to get an aphicide effect (measured as the total number of nymphs found dead) on the CFS of the three strains, the incubation time of 4 and 6 days had stronger aphicide effects than that of CFS incubated only one day. Although in diet with CFS of strain CBMDDrag3 the total number of nymphs did not differ from that found in the controls, all nymphs were found dead, which suggest that, even one day of incubation is enough to get aphicide effect. Since the three $B$. amyloliquefaciens strains, CBMDDrag3, PGPBacCA2, and CBMDLO3, were toxic to adults and nymphs of $M$. persicae, the strains CBMDDrag3 and CBMDLO3 at 4 days of incubation were selected for dose evaluation since they showed insecticidal effect on larvae and adults of Musca domestica (Torres, 2014). Finally, the CFS of CBMDLO3 strain had stronger aphicide effect over adults and nymphs of $M$. persicae than that of CBMDDrag3 at the three concentrations evaluated.

Aphids are hemimetabolous insects, with a complex life cycle that varies according to the environment. Parthenogenetic females generated on spring and summer are combined with a single annual sexual generation produced in late summer to overwinter as eggs (holocycle). M. persicae characteristic feature is its life-cycle variation, since as long as favorable conditions exist, the colony is built of parthenogenetic females that produce offspring in a viviparous manner. Newborn nymphs feed immediately and become adults in one week, resulting in a telescopic population growth. In tropical, sub-tropical, and temperate climates $M$. persicae can reproduce parthenogenetically throughout the year (anholocycle) and increase their pest potential (Blackman, 1974a,b). In temperate zones, potato crops sown in spring are a secondary host for $M$. persicae and are therefore threatened by the build-up of aphid populations. Under these circumstances, adult aphids must be quickly and effectively controlled to avoid an outbreak. Insecticides should kill adults fast to prevent the appearance of nymphs.

The composition of the lipopeptides produced by the strains CBMDDrag3 and CBMDLO3 of $B$. amyloliquefaciens was very diverse and depended on each strain. The lipopeptides produced by both strains were identified as homologs of kurstakins, surfactin, iturines, and fengicines (Table 6). Isolated lipopeptide fractions (LF) extracted from CFS of strains CBMDDrag3 and CBMDLO3 were not active against $M$. persicae, contrary to what was reported by Yun et al. (2013), who reported aphicidal activity by surfactins isolated from B. amyloliquefaciens applied topically to the dorsum of M. persicae. Yun et al. (2013) exposed aphids to purified surfactin applied topically while we exposed aphids to a blend of lipopeptides provided through the diet. According to our results, isolated lipopeptide fractions are not responsible for aphicidal activity present in CS and CFS, at least not when ingested by aphids. However, the negative effect of lipopeptides cannot be completely disregarded since they may need the presence of other bacterial metabolites that were not identified.

Overall, the finding that CS, hkCS, and CSF of the B. amyloliquefaciens acts on $M$. persicae in a short time with a high aphicidal effect, makes it a promising alternative to the development of a bacterial biopesticide. In potato crops, $M$. persicae is responsible for the spread of viruses that cause important economic losses. This aphid is also prone to develop resistance to synthetic pesticides. A microbiological pesticide made of a blend of compounds that act synergistically can minimize the development of such resistance. 


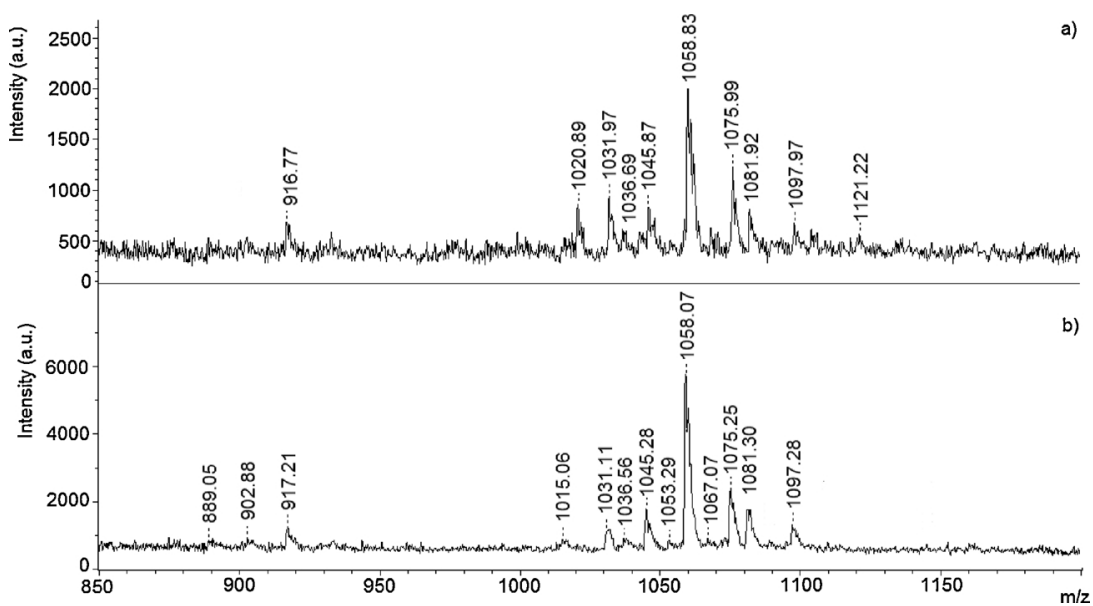

Fig. 2. UV-MALDI mass spectra of cell-free supernatant from B. amyloliquefaciens a) CBMDLO3, b) CBMDDrag3 in positive ion mode. Matrix: $\mathrm{nHo}$; $\mathrm{m} / \mathrm{z}$ range: 850 to 1200 .

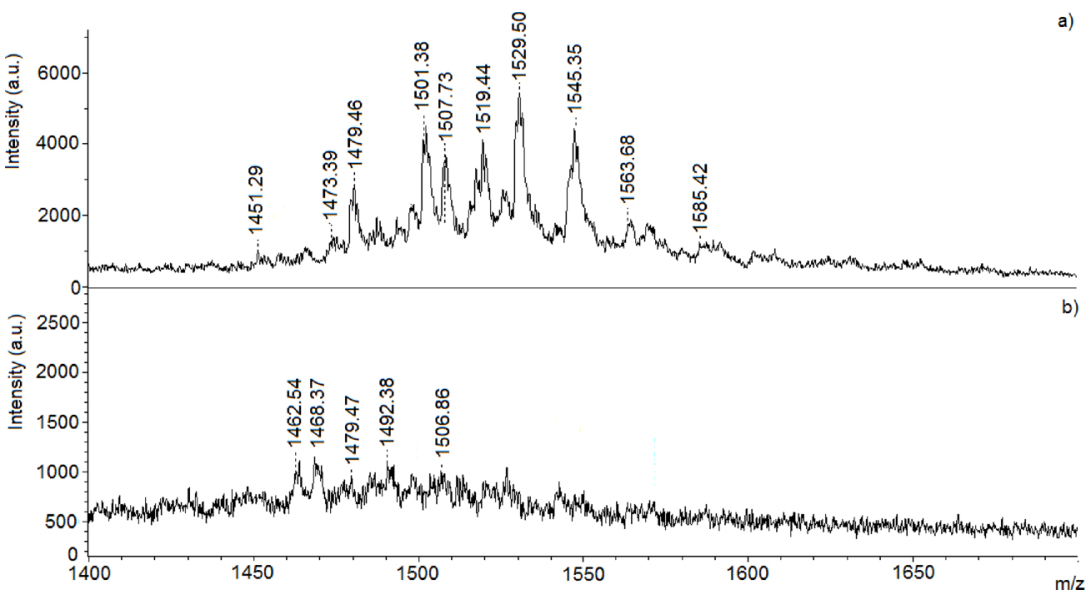

Fig. 3. UV-MALDI mass spectra of cell-free supernatant from B. amyloliquefaciens a) CBMDLO3, b) CBMDDrag3 in positive ion mode. Matrix: $\mathrm{nHo}$; $\mathrm{m} / \mathrm{z}$ range: 1400 to 1700 .

Table 6

Mass spectrometry analysis of lipopeptides produced by Bacillus amyloliquefaciens in Luria Bertani media at $37^{\circ} \mathrm{C}$. Experiments were conducted on two spots (duplicate) prepared with each individual sample.

\begin{tabular}{|c|c|c|c|c|}
\hline \multirow[t]{2}{*}{$m / z$} & \multicolumn{2}{|l|}{ Lipopeptide assignment } & \multirow[t]{2}{*}{ CBMDLO3 } & \multirow[t]{2}{*}{ CBMDDrag3 } \\
\hline & Name & Chemical formula & & \\
\hline 888 & Kurstakins & $\mathrm{C} 9[\mathrm{M}+\mathrm{K}]^{+}$ & - & + \\
\hline 902 & Kurstakins & $\mathrm{C} 10[\mathrm{M}+\mathrm{K}]^{+}$ & - & + \\
\hline 916 & Kurstakins & $\mathrm{C} 11[\mathrm{M}+\mathrm{K}]^{+}$ & + & + \\
\hline 1014 & Surfactin & $\mathrm{C} 12[\mathrm{M}+\mathrm{Na}]^{+}$ & - & + \\
\hline 1021 & Not assigned & & + & - \\
\hline 1030 & Surfactin & $\mathrm{C} 13[\mathrm{M}+\mathrm{Na}]^{+}$ & + & + \\
\hline 1036 & Surfactin & $\mathrm{C} 15[\mathrm{M}+\mathrm{H}]^{+}$ & + & + \\
\hline 1044 & Surfactin & $\mathrm{C} 14[\mathrm{M}+\mathrm{Na}]^{+}$ & + & + \\
\hline 1052 & Bacillomycin D & $\mathrm{C} 14[\mathrm{M}+\mathrm{Na}]^{+}$ & + & + \\
\hline 1058 & Surfactin & $\mathrm{C} 15[\mathrm{M}+\mathrm{Na}]^{+}$ & + & + \\
\hline 1066 & Bacillomycin D/iturin A & $\mathrm{C} 15[\mathrm{M}+\mathrm{Na}]^{+} / \mathrm{C} 14[\mathrm{M}+\mathrm{Na}]^{+}$ & - & + \\
\hline 1074 & Surfactin & $\mathrm{C} 15[\mathrm{M}+\mathrm{K}]^{+}$ & + & + \\
\hline 1080 & Bacillomycin D/iturin A & $\mathrm{C} 16[\mathrm{M}+\mathrm{Na}]^{+} / \mathrm{C} 14[\mathrm{M}+\mathrm{K}]^{+}$ & + & + \\
\hline 1096 & Bacillomycin D/iturin A & $\mathrm{C} 16[\mathrm{M}+\mathrm{K}]^{+} / \mathrm{C} 18[\mathrm{M}+\mathrm{H}]^{+}$ & + & - \\
\hline 1120 & Iturin A & $\mathrm{C} 18[\mathrm{M}+\mathrm{Na}]^{+}$ & + & + \\
\hline 1450 & Fengycin & Ala-6-C15[M+H] $]^{+}$ & + & - \\
\hline 1462 & Fengycin & Ala-6-C16 $[\mathrm{M}+\mathrm{H}]^{+}$ & - & + \\
\hline 1472 & Fengycin & Ala-6-C15[M + Na $]^{+}$ & + & - \\
\hline 1478 & Fengycin & Ala-6-C17[M+H $]^{+}$ & + & + \\
\hline 1492 & Fengycin & Val-6-C16[M+H] $]^{+}$ & - & + \\
\hline 1500 & Fengycin & Ala-6-C17[M + Na $]^{+}$ & + & - \\
\hline 1506 & Fengycin & Val-6-C17[M+H] ${ }^{+}$ & + & + \\
\hline 1528 & Fengycin & Val-6-C16[M + K $]^{+}$ & + & - \\
\hline 1544 & Fengycin & Val-6-C17[M + K $]^{+}$ & + & - \\
\hline 1562 & Fengycin & Val-6-C21[M + H] ${ }^{+}$ & + & - \\
\hline 1584 & Fengycin & Val-6-C21[M + Na] $]^{+}$ & + & - \\
\hline
\end{tabular}




\section{Acknowledgements}

The authors would like to thank CIUNSa (A-2305 and A-2331), University of Buenos Aires (20020130100055BA), CONICET (PIP 11220120100072CO), and National Science and Technology Promotion Agency (ANPCyT) of Argentina for the financial support (PICT-20150640, and PICT 2012-0888). The comments of Dr. Machado Assefh have been valuable for the improvement of the manuscript. GP, REB and MCA are Research Members of CONICET. GLI is a posdoctoral fellow of CONICET. The Ultraflex II (Bruker) TOF/TOF mass spectrometer was supported by a grant from ANPCYT, PME2003 No.125, CEQUIBIEM, DQB, FCEN, UBA.

\section{References}

Alvarez, F., Castro, M., Príncipe, A., Borioli, G., Fischer, S., Mori, G., Jofré, E., 2012. The plant-associated Bacillus amyloliquefaciens strains MEP218 and ARP23 capable of producing the cyclic lipopeptides iturin or surfactin and fengycin are effective in biocontrol of sclerotinia stem rot disease. J. Appl. Microbiol. 112, 159-174. https:// doi.org/10.1111/j.1365-2672.2011.05182.x

Atanasova, D., Leather, S.R., 2018. Plant essential oils: the way forward for aphid control? Ann. Appl. Biol. 1-5. https://doi.org/10.1111/aab.12451.

Bass, C., Puinean, A.M., Andrews, M., Cutler, P., Daniels, M., Elias, J., Paul, V.L., Crossthwaite, A.J., Denholm, I., Field, L.M., Foster, S.P., Lind, R., Williamson, M.S., Slater, R., 2011. Mutation of a nicotinic acetylcholine receptor b subunit is associated with resistance to neonicotinoid insecticides in the aphid Myzus persicae. BMC Neurosci. 12, 51. https://doi.org/10.1186/1471-2202-12-51.

Ben Khedher, S., Boukedi, H., Dammak, M., Kilani-Feki, O., Sellami-Boudawara, T., Abdelkefi-Mesrati, L., Tounsi, S., 2017. Combinatorial effect of Bacillus amyloliquefaciens AG1 biosurfactant and Bacillus thuringiensis Vip3Aa16 toxin on Spodoptera littoralis larvae. J. Invertebr. Pathol. 144, 11-17. https://doi.org/10.1016/j.jip.2017. 01.006.

Ben Khedher, S., Boukedi, H., Kilani-Feki, O., Chaib, I., Laarif, A., Abdelkefi-Mesrati, L., Tounsi, S., 2015. Bacillus amyloliquefaciens AG1 biosurfactant: Putative receptor diversity and histopathological effects on Tuta absoluta midgut. J. Invertebr. Pathol. 132, 42-47. https://doi.org/10.1016/j.jip.2015.08.010.

Beris, D., Theologidis, I., Skandalis, N., Vassilakos, N., 2018. Bacillus amyloliquefaciens strain MBI600 induces salicylic acid dependent resistance in tomato plants against Tomato spotted wilt virus and Potato virus y. Sci. Rep. 8, 1-11. https://doi.org/10 1038/s41598-018-28677-3.

Blackman, R., 1974a. Life-cycle variation of Myzus persicae (Sulz.) (Hom. Aphididae) in different parts of the world, in relation to genotype and environment. Bull. Entomol. Res. 63 (4), 595-607. https://doi.org/10.1017/S0007485300047830.

Blackman, R., 1974b. Aphids. Ginn \& Com. ed. London. Carlini, C. R., Grossi-de-Sá, M.F., 2002. Plant toxic proteins with insecticidal properties. A review on their potentialities as bioinsecticides. Toxicon 40, 1515-1539.

Castle, S.J., Berger, P.H., 1993. Rates of growth and increase of Myzus persicae on virusinfected potatoes according to type of virus-vector relationship. Entomol. Exp. Appl. 69, 51-60. https://doi.org/10.1007/BF02380673.

Chandler, D., Bailey, A.S., Mark Tatchell, G., Davidson, G., Greaves, J., Grant, W.P., 2011. The development, regulation and use of biopesticides for integrated pest management. Philos. Trans. R. Soc. B Biol. Sci 366, 1987-1998. https://doi.org/10.1098/ rstb.2010.0390.

Devonshire, A.L., Field, L.M., 1991. Gene amplification and insecticide resistance. Annu. Rev. Entomol. 36, 1-23. https://doi.org/10.1146/annurev.en.36.010191.000245.

Devonshire, A., Field, L.M., Foster, S.P., Moores, G.D., Williamson, M.S., Blackman, R.L., 1998. The evolution of insecticide resistance in the peach-potato aphid, Myzus persicae. Philos. Trans. R. Soc. B Biol. Sci 353, 1677-1684. https://doi.org/10.1098/ rstb.1998.0318.

Di Rienzo, J.A., Casanoves, F., Balzarini, M.G., Gonzalez, L., Tablada, M., Robledo, C.W., 2015. InfoStat versión 2015. Grupo InfoStat FCA, Universidad Nacional de Córdoba, Argentina.

Douglas, A.E., 1998. Nutritional interactions in insect-microbial symbioses: aphids and their symbiotic Bacteria Buchnera. Annu. Rev. Entomol. 43, 17-37. https://doi.org/ 10.1146/annurev ento. 43.1.17.

Douglas, A.E., 1996. Reproductive failure and the free amino acid pools in pea aphids (Acyrthosiphon pisum) lacking symbiotic bacteria. J. Insect Physiol. 42, 247-255.

Ekström, G., Ekbom, B., 2011. Pest control in agro-ecosystems: an ecological approach. Crit. Rev. Plant Sci. 30, 74-94. https://doi.org/10.1080/07352689.2011.554354.

Garzo, E., Moreno, A., Hernando, S., Mariño, V., Torne, M., Estrella, M., Díaz, I., Fereres, A., 2015. Electrical Penetration Graph technique as a tool to monitor early stages of aphid resistance to insecticides. Pest Manag. Sci. 72, 707-718. https://doi.org/10. 1002/ps.04041.

Geetha, I., Manonmani, A.M., Prabakaran, G., 2011. Bacillus amyloliquefaciens: a mosquitocidal bacterium from mangrove forests of Andaman \& Nicobar islands. India. Acta Trop. 120, 155-159. https://doi.org/10.1016/j.actatropica.2011.07.006.

Hill, D.S., 2008. Pests of Crops in Warmer Climates and Their Control. United Kingdom.

Isman, M.B., 2006. Botanical insecticides, deterrents, and repellents in modern agriculture and an increasingly regulated world. Annu. Rev. Entomol. 51, 45-66. https:// doi.org/10.1146/annurev.ento.51.110104.151146.

Jeffries, C.J., 1998. Potato. Thechnical Guiedelines for the Safe Movement of Germoplasm. Rome FAO/IPGRI.

Kim, P.I., Bai, H., Bai, D., Chae, H., Chung, S., Kim, Y., Park, R., Chi, Y.T., 2004. Purification and characterization of a lipopeptide produced by Bacillus thuringiensis CMB26. J. Appl. Microbiol. 97, 942-949. https://doi.org/10.1111/j.1365-2672. 2004.02356.x.

Koga, R., Tsuchida, T., Sakurai, M., Fukatsu, T., 2007. Selective elimination of aphid endosymbionts: effects of antibiotic dose and host genotype, and fitness consequences. FEMS Microbiol. Ecol. 60, 229-239. https://doi.org/10.1111/j.15746941.2007.00284.x.

Kuroli, G., Lantos, Z., 2006. Long-term study of alata Aphid flight activity and abundance of potato colonizing Aphid species. Acta Phytopathol. Entomol. Hungarica 41, 261-273. https://doi.org/10.1556/APhyt.41.2006.3-4.9.

Loebenstein, G., Berger, P.H., Brunt, A.A., Lawson, R.H., 2001. Virus and Virus-like Diseases of Potatoes and Production of Seed-potatoes. Springer. edhttps://doi.org/ 10.1007/978-94-007-0842-6.

Machado-Assefh, C.R., Lopez-Isasmendi, G., Tjallingii, W.F., Jander, G., Alvarez, A.E., 2015. Disrupting Buchnera aphidicola, the endosymbiotic bacteria of Myzus persicae, delays host plant acceptance. Arthropod. Interact. https://doi.org/10.1007/s11829015-9394-8.

Machado-Assefh, C.R., Alvarez, A.E., 2018. Probing behavior of aposymbiotic green peach aphid (Myzus persicae) on susceptible Solanum tuberosum and resistant Solanum stoloniferum plants. Insect Sci. 25, 127-136. https://doi.org/10.1111/1744-7917. 12372.

Mnif, I., Ghribi, D., 2015. Potential of bacterial derived biopesticides in pest management. Crop Prot. 77, 52-64. https://doi.org/10.1016/j.cropro.2015.07.017.

Moores, G.D., Devine, G.J., Devonshire, A.L., 1994. Insecticide-insensitive acetylcholinesterase can enhance esterase-based resistance in Myzus persicae and Myzus nicotianae. Pestic. Biochem. Physiol. https://doi.org/10.1006/pest.1994.1038.

Ongena, M., Duby, F., Jourdan, E., Beaudry, T., Jadin, V., Dommes, J., Thonart, P., 2005. Bacillus subtilis M4 decreases plant susceptibility towards fungal pathogens by increasing host resistance associated with differential gene expression. Appl. Microbiol. Biotechnol. 67, 692-698. https://doi.org/10.1007/s00253-004-1741-0.

Ongena, M., Jacques, P., 2007. Bacillus lipopeptides: versatile weapons for plant disease biocontrol. Trends Microbiol. 16, 115-125. https://doi.org/10.1016/j.tim.2007.12. 009.

Porrini, M.P., Audisio, M.C., Sabaté, D.C., Ibarguren, C., Medici, S.K., Sarlo, E.G., Garrido, P.M., Eguaras, M.J., 2010. Effect of bacterial metabolites on microsporidian Nosema ceranae and on its host Apis mellifera. Parasitol. Res. 107, 381-388. https://doi.org/ 10.1007/s00436-010-1875-1.

Prosser, W., Douglas, A.E., 1991. The aposymbiotic aphid : an analysis of chlortetracycline-treated pea aphid, Acyrthosiphon pisum. J. Insect Physiol. 37, 713-719.

Radcliffe, E.B., Ragsdale, D.W., 2002. Aphid-transmitted potato viruses: the importance of understanding vector biology. Am. J. Potato Res. 79, 353-386. https://doi.org/10. 1007/BF02870173.

Sabaté, D.C., Carrillo, L., Audisio, M.C., 2009. Inhibition of Paenibacillus larvae and Ascosphaera apis by Bacillus subtilis isolated from honeybee gut and honey samples. Res. Microbiol. 160, 193-199. https://doi.org/10.1016/j.resmic.2009.03.002.

Salazar, L.F., 1996. Potato Viruses and Their Control. Internatio. ed. Lima, Perú.

Simon, J.C., Peccoud, J., 2018. Rapid evolution of aphid pests in agricultural environments. Curr. Opin. Insect Sci. 26, 17-24. https://doi.org/10.1016/j.cois.2017.12. 009.

Stavrinides, J., McCloskey, J.K., Ochman, H., 2009. Pea aphid as both host and vector for the phytopathogenic bacterium Pseudomonas syringae. Appl. Environ. Microbiol. 75 , 2230-2235. https://doi.org/10.1128/AEM.02860-08.

Tjallingii, W., Hogen Esch, T., 1993. Fine structure of aphid stylet routes in plant tissues in correlation with EPG signals. Physiol. Entomol. 18, 317-328.

Torres, M.J., Pérez Brandan, C., Sabaté, D.C., Petroselli, G., Erra-Balsells, R., Audisio, M.C., 2017. Biological activity of the lipopeptide-producing Bacillus amyloliquefaciens PGPBacCA1 on common beanPhaseolus vulgaris L. pathogens. Biol. Control 105, 93-99. https://doi.org/10.1016/j.biocontrol.2016.12.001.

Torres, M.J., 2014. Estudio Y Caracterización De Compuestos De Origen Bacteriano Para El Biocontrol De Patógenos. PhD Thesis. Fac. de Cs. Exactas, UNSa, Salta. Argentina.

van Toor, R.F., Foster, S.P., Anstead, J.A., Mitchinson, S., Fenton, B., Kasprowicz, L., 2008. Insecticide resistance and genetic composition of Myzus persicae (Hemiptera: aphididae) on field potatoes in New Zealand. Crop Prot. 27, 236-247. https://doi. org/10.1016/j.cropro.2007.05.015.

van Toor, R.F., Malloch, G.L., Anderson, E., Dawson, G., Fenton, B., 2013. Insecticide resistance profiles can be misleading in predicting the survival of Myzus persicae genotypes on potato crops following the application of different insecticide classes. Pest Manag. Sci. 69, 93-103. https://doi.org/10.1002/ps.3370.

Weisstein, E.W., 1999. Bonferroni Correction. From Math-Worlda Wolfram Web Resource. 1999-2007, Wolfram Research, Inc. http://mathworld.wolfram.com/ BonferroniCorrection.html.

Yun, D.C., Yang, S.Y., Kim, Y.C., Kim, I.S., Kim, Y.H., 2013. Identification of surfactin as an aphicidal metabolite produced by Bacillus amyloliquefaciens G1. J. Korean Soc. Appl. Biol. Chem. 56, 751-753. https://doi.org/10.1007/s13765-013-3238-y.

Zouari, I., Jlaiel, L., Tounsi, S., Trigui, M., 2016. Biocontrol activity of the endophytic Bacillus amyloliquefaciens strain CEIZ-11 against Pythium aphanidermatum and purification of its bioactive compounds. Biol. Control 100, 54-62. https://doi.org/10. 1016/j.biocontrol.2016.05.012. 